\title{
Trichogranulomatous mastopathy: an unusual cause of bleeding from the nipple
}

\author{
J. R. GOEPEL \\ M.B., Ch.B., M.R.C.Path. \\ University Department of Pathology, Royal Hallamshire Hospital, Sheffield S10 2JF
}

\begin{abstract}
Summary
A case of bleeding from the nipple is presented which was due to fragments of hair within breast ducts. It is suggested that these were accidentally introduced through the nipple.
\end{abstract}

\section{Case report}

A 53-year-old childless widow presented with a history of 3 episodes of bleeding and greenish discharge from the right nipple 2 months previously. Two months before the bleeding the nipple had become inverted. Her previous history included operations for a colloid goitre and a hysterectomy. Examination revealed slight induration inferior to the nipple but no discharge could be expressed. A right inferior microdochotomy was performed and a portion of breast tissue $4 \times 3 \times 0.6 \mathrm{~cm}$ removed. Histology showed one duct and 2 of its branches contained fragments of hair shaft extending along $10 \mathrm{~mm}$; this was associated with focal ulceration of the duct epithelium and bleeding into the lumen (Fig. 1). Some fragments of hair had penetrated the duct wall and elicited a foreign body reaction in periductal tissue. The involved ducts were surrounded by an inflammatory infiltrate of lymphocytes and plasma cells with scattered poly- 은 morphs. No intraduct papilloma was present; the remainder of the breast tissue showed a minor degree of cystic disease without duct ectasia or metaplasia of the duct epithelium.

Discussion

A bloody discharge from the nipple is most frequently due to an intraduct papilloma though. occasionally a carcinoma may be the cause; onl rarely is the origin from a non-neoplastic condition

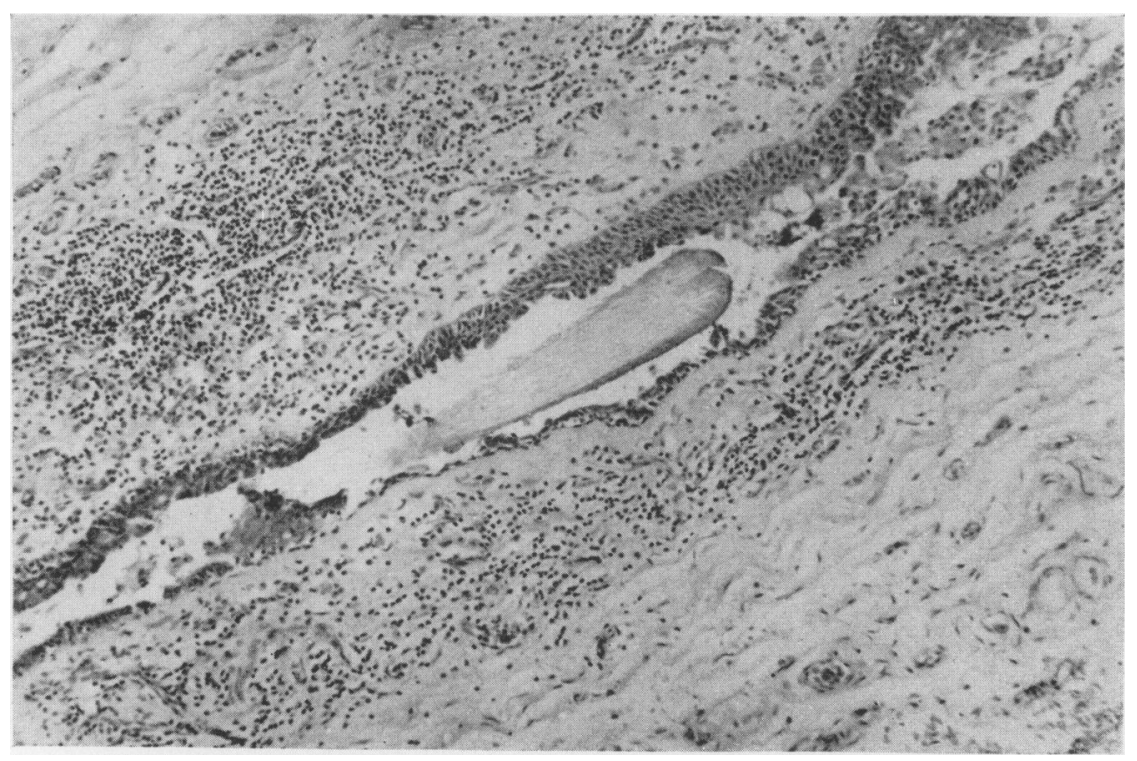

FIG. 1. Portion of hair shaft within a breast duct showing ulceration and bleeding. 0032-5473/80/1200-0850 \$02.00 (C) 1980 The Fellowship of Postgraduate Medicine 
such as pregnancy or duct ectasia (Haagensen, 1971). The case presented, however, shows the bleeding to be related to the presence of fragments of hair shaft within ducts. Willis (1958), discussing metaplasia in the breast, records a very similar case, although the character of the nipple discharge is not stated. $\mathrm{He}$ forms the opinion that the hair grew locally in an area of metaplasia which was subsequently destroyed by inflammation. This case shows no abnormality of the duct epithelium apart from focal ulceration and the author's opinion is that the hair is a foreign body introduced accidentally through the nipple.

\section{Acknowledgments}

The author is grateful to Dr J. C. E. Underwood for encouragement and advice, and to $\mathrm{Dr} J$. D. Davies, University Department of Pathology, Bristol, for reviewing the case material and manuscript. Also to $\mathrm{Mr} \mathrm{W}$. Morris Jones for access to clinical data and Mrs R. Raine for typing the manuscript.

\section{References}

HaAgensen, C.D. (1971) Diseases of the Breast, 2nd edn, p. 102. Saunders, Philadelphia.

WILLIS, R.A. (1958) The Borderland of Embryology and Pathology, p. 508. Butterworth, London. 